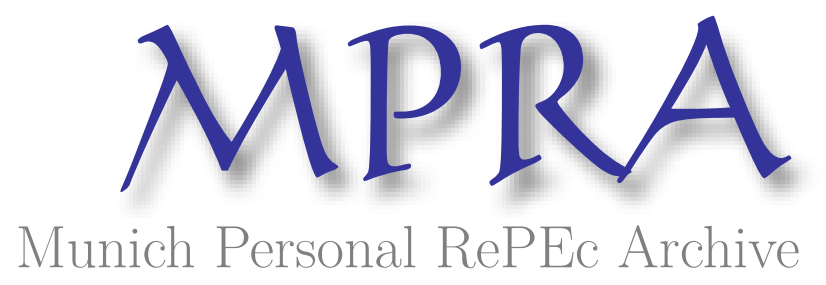

\title{
Population growth and endogenous technological change: Australian economic growth in the long run
}

Banerjee, Rajabrata

March 2011

Online at https://mpra.ub.uni-muenchen.de/30892/

MPRA Paper No. 30892, posted 13 May 2011 02:43 UTC 


\title{
Population Growth and Endogenous Technological Change: Australian Economic Growth in the Long Run*
}

\author{
RAJABRATA BANERJEE \\ School of Commerce, \\ University of South Australia, \\ Adelaide, South Australia, Australia
}

This version: $10^{\text {th }}$ March, 2011

\begin{abstract}
The Australian growth experience appears to be a three-act phenomenon, with higher per capita income and living standards before 1890 and after 1940, disconnected by a 50-year period of no trend improvement in between. This paper examines the roles of technological progress and population growth in Australian productivity growth over the past two centuries. The empirical results confirm that while population growth had a negative effect, innovative activity had a positive effect on productivity growth. Furthermore, the estimates strongly support the Schumpeterian growth hypothesis, which predicts that productivity growth is driven by the levels of research intensity in the economy.
\end{abstract}

Keywords: endogenous growth, technological progress, population JEL Classifications: O30; O40

\footnotetext{
* Correspondence: School of Commerce, University of South Australia, GPO Box 2471, Adelaide SA 5001, Australia. email: Rajabrata.banerjee@unisa.edu.au Acknowledgements: In conducting this research, the author gratefully acknowledges research grant support from the School of Commerce, University of South Australia.
} 


\section{Introduction}

Per capita GDP and living standards in Australia were much higher than in the US and Britain prior to 1890 (Greasley and Oxley, 1997, 1998, McLean, 2004). However, Australia could not maintain this lead in the twentieth century. The Australian growth experience appears to be a three-act phenomenon, with higher per capita income and living standards before 1890 and after 1940, disconnected by 50 years of no trend improvement in between (McLean and Pincus, 1983, Jackson, 1992, McLean, 2004). While the five years' average total factor productivity (TFP) growth in the period $1840-1890$ was $6.03 \%$, the growth rate dropped to $0.76 \%$ in the period 1891-1940. In the subsequent periods of 1941-1970 and 1971-2008, the five years' average TFP growth rate was $10.26 \%$ and $4.46 \%$, respectively. 1 What are the principal factors behind this dramatic growth failure in the first half of the twentieth century? Did slower technological progress contribute to the sluggish growth in this period? Has population growth had a negative effect on productivity growth during the past two centuries?

Recent literature on economic growth has found some striking results about the roles of technological progress and population growth in explaining historical events such as the Industrial Revolution in Britain and the Great Divergence. The unified theories of economic growth of Goodfriend and McDermott (1995), Galor and Weil (2000), Hansen and Prescott (2002) and Lucas (2009) all focus on innovations and population growth as the principal drivers of per capita income growth. Madsen et al. (2010a) find that, due to land being a fixed factor of production, during the period of the First Industrial Revolution in Great Britain (1760-1850), population growth outpaced technological progress and resulted in slower growth. The growth rate increased during the Second Industrial Revolution (1850-1913), with lower population growth and higher technological progress in the economy. Despite the

\footnotetext{
${ }^{1}$ Author's calculation based on data sources listed in the appendix.
} 
fact that Australia has shared close economic ties with Britain from circa $1870 \mathrm{~s}^{2}$, it is yet to be examined whether Australia experienced similar attributes in its three-act growth phenomenon, before 1890, 1890-1940 and 1940-1970, respectively.

Maddock and McLean (1987) outline the major events that Australia has experienced since 1800 and propose that the depression of the 1890 s was the first major recession in the economy since that of the 1840s. Their research highlights that the major factors for the downturn were the failure of the wool industry, undesirable heavy investment by government on infrastructure developments, a speculative property boom centred in Melbourne and the failure of the London capital market. The economy was beginning to recover in the second half of the 1890s, but a severe drought at the turn of the century followed by the First World War in 1914 delayed the growth process by several decades.

Consequently, the recession of the 1890 s became a significant marker in the history of macroeconomic growth in Australia (Jackson, 1977). Butlin (1962) and Boehm (1971) suggest that the collapse was a result of a payments imbalance, creating debt from excess commodity exports such as wool, gold and agricultural and mineral products. This in turn could not serve the increased population and eroded Australia's natural resource advantages by weakening the terms of trade (Oxley and Greasley, 1995, Greasley and Oxley, 1998).

In contrast, a more recent survey by McLean (2004) finds that the depression of the 1890 s does not appear to have shifted the nature of the growth process. In spite of manufacturing growth, primary commodity exports and dependence on rural development continued until the First World War and resumed in the 1920s. Further, the boom period after 1945 has many characteristics in common with that of the late nineteenth century, such as an export boom in wool and other agricultural and mineral products, higher immigration and

${ }^{2}$ Greasley and Oxley (1998) empirically find a significant linkage of economic ties between Australia and Britain and between the US and Canada from 1870. 
higher foreign investment. Thus, the puzzle surrounding the late-nineteenth-century depression is far from being solved.

Despite the importance of technological progress in advancing the productivity growth of advanced economies, very little work, if any, has been undertaken to explain Australian productivity growth based on innovative activity over past centuries. Kaspura and Weldon (1980) argue that in the early twentieth century Australia stayed in the factor accumulation stage for a longer period than the US and had a slower transition of growth from factor accumulation to total factor productivity. The US shares similar characteristics of natural resource abundance to Australia, however, at the turn of the twentieth century, US growth was dependent more on knowledge creation than on factor accumulation. Whether slower transition to growth is due to slower technological progress is worth examining in the case of Australia (McLean, 2004).

In terms of the present political debate concerning the opening up of Australia's borders to the international world, it is important to examine empirically the effect of population growth in the context of the country's historical growth. The objectives of this paper are: 1) to examine the roles of technological progress and population growth in the context of Australian productivity growth over the past two centuries, and 2) to examine whether there was slower technological progress in the first half of the twentieth century. In doing so, the paper takes an endogenous technological approach following the second-generation Schumpeterian growth model of Aghion and Howitt (1998), Howitt (1999), Peretto and Smulders (2002) and Ha and Howitt (2007).

The paper proceeds as follows. The next section discusses the theoretical basis of this study following Ha and Howitt (2007), Madsen (2008) and Madsen, et al. (2010a) and details 
the empirical methodology used. Section 3 presents the empirical analysis and discusses the results. Section 4 concludes the analysis.

\section{The Australian Economy and the Schumpeterian Growth}

\section{Model}

\subsection{Theoretical Model}

From the early nineteenth century, Australian land was an involuntary gift to the Europeans, an export without charge (Meredith and Dyster, 1999). Since then land has been an important factor of production in Australia, where the internal and external markets are mainly dominated by primary commodities such as agricultural products and mineral products. However, when land is a significant factor of production, labour productivity growth is a race between population growth and technological progress, as shown below.

Consider the following homogenous Cobb-Douglas production function:

$Y_{t}=A_{t} K_{t}^{\alpha\left(1-\beta_{t}\right)} T_{t}^{\beta_{t}} L_{t}^{(1-\alpha)\left(1-\beta_{t}\right)}$

where $Y_{t}$ is real output, $A_{t}$ is the knowledge stock, $K_{t}$ is the capital stock, $T_{t}$ is land, $L_{t}$ is labour, $\alpha\left(1-\beta_{t}\right)$ is the share of income going to capital and $\beta_{t}$ is the share of income going to land under the maintained assumption of perfect competition. The production function exhibits constant returns to scale in $K_{t}, T_{t}$ and $L_{t}$ and increasing returns to scale in $A_{t}, K_{t}, T_{t}$ and $L_{t}$ together.

In terms of per worker output,

$\frac{Y_{t}}{L_{t}}=A_{t}^{\frac{1}{1-\alpha\left(1-\beta_{t}\right)}}\left[\frac{K_{t}}{Y_{t}}\right]^{\frac{\alpha\left(1-\beta_{t}\right)}{1-\alpha\left(1-\beta_{t}\right)}} T_{t}^{\psi_{t}} L_{t}^{-\psi_{t}}$ 
where $\psi_{t}=\beta_{t} /\left[1-\alpha\left(1-\beta_{t}\right)\right]$. Labour productivity is expressed in terms of the $\mathrm{K}-\mathrm{Y}$ ratio to filter out technology-induced capital deepening (Klenow and Rodriguez-Clare, 1997). ${ }^{3}$

Along the balanced growth path and under the assumption that land is a fixed factor of production, taking logs and differentiating Equation (2) follows:

$$
g_{y_{t}}=\frac{\psi_{t}}{\beta_{t}} g_{A_{t}}-\psi_{t} g_{L_{t}}
$$

where $g_{y}$ is labour productivity growth, $g_{A}$ is growth in TFP and $g_{L}$ is growth in the labour force. The role of capital for growth is suppressed in Equation (3) under the assumption that the economy is on its balanced growth path in which the $\mathrm{K}-\mathrm{Y}$ ratio is constant. Capital deepening cannot act as an independent growth factor since it is driven entirely by technological progress along the balanced growth path.

In the case where land is omitted as a factor of production $(\beta=0)$, Equation (3) reduces to a standard neoclassical growth model, and along the balanced growth path labour productivity growth is driven entirely by technological progress, independent of population growth. This is because capital stock endogenously adjusts until the $K-Y$ ratio returns to its initial level following a population shock. When land is an essential factor of production, population growth reduces labour productivity. Population growth slows growth in Equation (3) because of diminishing returns introduced by land as a fixed factor of production. The greater the importance of agricultural production in total output, the more population growth acts as a growth-drag on the economy.

Although population affects growth directly, innovative activity influences growth positively and indirectly through the channel of the production of ideas. While there are three

\footnotetext{
${ }^{3}$ See Madsen, et al. (2010a) for why productivity growth triggers capital deepening.
} 
established endogenous growth theories, each having different implications on productivity growth, only one has gained wide support in the recent literature. ${ }^{4}$ The first-generation models of Romer (1990) and Aghion and Howitt (1992) predict a positive relationship between the levels of research effort and productivity growth. However, following the famous critique of Jones (1995a, b), the first-generation endogenous growth models are no longer considered to have any empirical validity. ${ }^{5}$ Consequently, Jones (1995a) developed the semi-endogenous growth model that could explain the US growth experience after 1950.

Semi-endogenous growth models suggest that it is the relative change and not the level of research effort that influences growth. However, the evolution of growth theories continued with the second-generation Schumpeterian growth models, which assume that growth is proportional to research intensity, defined as research effort divided by product variety (Aghion and Howitt, 1998, Howitt, 1999, Peretto and Smulders, 2002). While empirically the Schumpeterian model has gained wide support from various researchers for modern and historical time periods, the semi-endogenous growth model has garnered almost no support in any of the occurrences (Ha and Howitt, 2007, Madsen, 2008, Ang et al., 2010, Madsen, et al., 2010a, Madsen et al., 2010b). ${ }^{6}$

Following the Schumpeterian growth model, the growth of ideas is a function of R\&D inputs and other variables:

$\frac{\dot{A}}{A}=\lambda\left(\frac{X}{Q}\right)^{\sigma} \Rightarrow g_{A}=\lambda\left(\frac{X}{Q}\right)^{\sigma}, 0<\sigma \leq 1$

\footnotetext{
${ }^{4}$ See Ha and Howitt (2007) for a detailed discussion on various endogenous growth theories and their implications.

${ }^{5}$ The evidence was also supported by Ha and Howitt (2007) and Madsen (2008): while the number of R\&D workers in the OECD countries has increased substantially over the past century, their growth rates have changed little.

${ }^{6}$ Although in this paper, empirical methodology follows the Schumpeterian growth model, empirical prediction following semi-endogenous growth model was also tested. However, the results are not reported here since they were insignificant in most cases. In addition, the focus of this study is not the testing of endogenous growth models and thus rigorous empirical analysis of the validity of the various growth models is outside its scope.
} 
where $\mathrm{g}_{\mathrm{A}}$ is the growth of knowledge, $\lambda$ is the research productivity parameter, $X$ is the $\mathrm{R} \& \mathrm{D}$ input, $\sigma$ is the duplication parameter which is zero if all innovations are duplications and one if none is a duplication and $Q$ is product proliferation variable which is assumed to grow at the same rate of population $(L)$ in the long run.

\subsection{Empirical Methodology}

Following the theoretical model presented in the previous section, cointegration and growth regression are carried out to examine the effects of innovative activity and population growth on labour productivity growth and total factor productivity growth since 1840 . Assuming that shocks, $e_{t}$, are identically and normally distributed with a mean of zero, Equation (4) forms the following model (see Ha and Howitt, 2007):

$\Delta \ln A_{t}=\ln \lambda+\sigma\left[\ln X_{t}-\ln Q_{t}\right]+e_{t}$

Imposing the restrictions suggested by the model implies that the term $\varphi_{t}$ in the following equation is stationary:

$\varphi_{t}=\ln X_{t}-\ln Q_{t}$

Schumpeterian growth theory predicts that (i) $\ln (X / Q)_{t}$ is stationary and (ii) $\ln X_{t}$ and $\ln Q_{t}$ are cointegrated with the cointegrated vector of $[1,-1]$. Here, $X_{t}$ is measured by patents applications by domestic residents and $Q$ is measured by labour force $\left(L_{t}\right)$.

However, cointegration tests are necessary but not sufficient conditions for secondgeneration growth models to be consistent with the growth process (see Madsen, 2008). A sufficient condition is that the model can explain long-run growth. Further, this study examines the effect of innovative activity on the one hand and population growth on the other in the Australian economy over the past two centuries. Hence, it is necessary to run regression models that include innovative activity and population growth variables 
simultaneously in the estimation equations. In the Schumpeterian model, Equation (4) generates $\Delta \ln A=\ln \left(\frac{A_{t}}{A_{t-1}}\right)$. A linear approximation yields:

$\ln \left(\frac{A_{t}}{A_{t-1}}\right) \simeq \frac{A_{t}}{A_{t-1}}-1=g_{A}=\lambda\left(\frac{X}{Q}\right)^{\sigma}$

Thus the $X / Q$ variable enters into the regression models in levels. ${ }^{7}$ Assuming linear transformation, the following growth equations are regressed:

$$
\begin{aligned}
& \Delta \ln y_{t}=a_{0}+a_{1}\left(\frac{X}{Q}\right)_{t}+a_{2} \Delta \ln P_{t}+a_{3} D+a_{4} \Delta \ln T O_{t}+a_{5} \Delta \ln L E_{t}+a_{6} \ln U N C_{t}+e_{t}(8) \\
& \Delta \ln y_{t}=b_{0}+b_{1}\left(\frac{X}{Q}\right)_{t-1}+b_{2} \Delta \ln P_{t-1}+b_{3} D+b_{4} \Delta \ln T O_{t}+b_{5} \Delta \ln L E_{t}+b_{6} \ln U N C_{t}+u_{t},
\end{aligned}
$$

where $y_{t}$ can take values of labour productivity $(Y / L)$ or total factor productivity $\left(T F P_{t}\right), X$ is patents applications by domestic residents, $Q$ is labour force $(L), P$ is population, TO represents trade openness, measured as the sum of imports and exports over nominal GDP, $L E$ is life expectancy and finally $U N C$ measures macro economic uncertainty, calculated as the five-year standard deviation of annual growth in CPI. To examine whether there was a slower productivity growth induced by slower technological progress and higher population growth in the depression years, a dummy variable $(D)$ was introduced in the regression models, which takes the value one in the period 1891-1940 and zero otherwise. All growth estimations are calculated on a five-year non-overlapping series on annual figures to reduce the effect of business cycles. The data sources for each variable are in the appendix. The difference between Equations (8) and (9) is that the latter captures slow adjustment of productivity to innovation and ensures that there are no feedback effects from labour productivity to innovative activity and population growth rates.

\footnotetext{
${ }^{7}$ Although the growth specification for the Schumpeterian model yields X/Q to be entered in growth regressions in levels and not in logs, none of the previous studies in which a test of the Schumpeterian model is examined empirically has followed it correctly. All previous studies have entered the specification for X/Q in logs.
} 
Patent applications are the only currently available historical data for measuring innovative activity. Yet past studies have argued for and against patent applications as an indicator of innovative activity. The major concerns against patent applications are that the quality of patents varies over time, not all innovations are patented, the propensity to patent may change over time, and the high costs of patenting give inventors strong incentives to keep their inventions secret (Boehm and Silberston, 1967). These criticisms necessarily indicate that patents might be a noisy indicator in estimations and, as such, may bias the parameter estimates towards zero.

Nonetheless, if the estimates prove significant and positive, it will essentially mean that the coefficients are still understating the importance of innovative activity. Griliches (1990) concludes, 'in spite of all the difficulties, patent statistics remain a unique resource for the analysis of the process of technical change'. Further, Madsen (2007) finds that that there is constant returns to $\mathrm{R} \& \mathrm{D}$, which implies that there is proportionality between $\mathrm{R} \& \mathrm{D}$ and patent applications. Thus, taking all evidence into consideration, there should be few problems in using patents as an indicator of innovative activity in empirical estimations. In the literature the measure is very common to capture innovations and technological progress (see Sullivan, 1989, 1990, Oxley and Greasley, 1998, Greasley and Oxley, 2007, Madsen, 2008, Ang, et al., 2010, Madsen, et al., 2010a).

Although trade openness is entered into the regressions as a control variable, the measure can indicate some important characteristics for Australian economic growth, particularly in the late nineteenth and early twentieth centuries. Export-led growth is often considered a prime factor of Australian economic growth from the early 1870s, when wool and other agricultural and mineral products were exported to the international economy. Further, over-exporting of commodities is held responsible for the depression around the 1890s (Oxley and Greasley, 1995, Greasley and Oxley, 1998). Hence, the variable is 
expected to be positive for Australian growth regressions in its boom periods. While trade openness is not an ideal proxy for openness, better data on openness, such as tariffs and nontariff trade barriers, are not available for the early periods.

Life expectancy and macroeconomic uncertainty are included in the regressions as additional control variables. Productivity growth is often assumed to be a positive function of life expectancy because the incentives to invest in the future are positively correlated with the number of years in which an individual is expected to be productive (see Cervellati and Sunde, 2005). The longer an individual is expected to live the larger are the expected returns to schooling. Furthermore, since a long life often goes hand-in-hand with a healthy life, an individual that is expected to live longer is likely to be more productive during their adult years. Inflation variability, as a proxy for macroeconomic uncertainty, is a drag on the economy because it is often associated with fiscal mismanagement, wars and crop failures. The next section presents and discusses the empirical results.

\section{Empirical Results}

Unit root tests are necessary before performing any cointegration test. Three different unit roots tests, namely the Augmented Dickey Fuller test (ADF), the Phillips-Perron test (PP) and the Zivot-Andrews test (ZA), are carried out for each variable, where the last test accounts for one structural break in the series over time. ${ }^{8}$ The variables are: total factor productivity (TFP), labour productivity (LP), patent applications (X), labour force (L), population $(\mathrm{P})$ and research intensity measured by patents applications divided by labour force $(\mathrm{X} / \mathrm{L})$. Table 1 below shows the unit test results of the variables.

Unit root test results in Table 1 suggest that $\ln$ TFP, $\ln$ LP and $\ln \mathrm{X}$ and $\ln \mathrm{P}$ are integrated in order one, regardless of which test is applied. Although $\ln \mathrm{L}$ is found to be $\mathrm{I}(0)$

\footnotetext{
${ }^{8}$ See Zivot and Andrews (1992) for unit root test with one unknown structural break.
} 
in the conventional ADF and PP tests, the variable is found to be $\mathrm{I}(1)$ when allowed for a structural break in ZA test. Finally, $\ln (\mathrm{X} / \mathrm{L})$ is found to be $\mathrm{I}(0)$ regardless of which test is performed. The result supports the condition for Schumpeterian theory, outlined in the previous section.

Table 1: Unit Root Test Results

\begin{tabular}{|c|c|c|c|c|c|c|c|}
\hline \multirow[t]{2}{*}{ Variable } & \multicolumn{2}{|c|}{ ADF } & \multicolumn{3}{|c|}{ PP } & $\mathrm{ZA}$ & \multirow[t]{2}{*}{ Result } \\
\hline & Level & $\begin{array}{l}1^{\text {st }} \\
\text { Difference }\end{array}$ & Level & $\begin{array}{l}1^{\text {st }} \\
\text { Difference }\end{array}$ & Level & $\begin{array}{l}1^{\text {st }} \\
\text { Difference }\end{array}$ & \\
\hline $\begin{array}{l}\text { Total factor } \\
\text { productivity } \\
{[\ln T F P]}\end{array}$ & $\begin{array}{l}-2.72 \\
(0.23)\end{array}$ & $\begin{array}{l}-14.98^{\text {***k }} \\
(0.00)\end{array}$ & $\begin{array}{l}-2.89 \\
(0.17)\end{array}$ & $\begin{array}{l}-14.88^{* * *} \\
(0.00)\end{array}$ & $\begin{array}{l}-4.71 \\
(\mathrm{BP}=1948)\end{array}$ & $\begin{array}{l}-7.87^{\text {*** }} \\
(\mathrm{BP}=1933)\end{array}$ & $\mathrm{I}(1)$ \\
\hline $\begin{array}{l}\text { Labour } \\
\text { productivity } \\
{[\ln L P]}\end{array}$ & $\begin{array}{l}-1.89 \\
(0.66)\end{array}$ & $\begin{array}{l}-15.53^{\text {**** }} \\
(0.00)\end{array}$ & $\begin{array}{l}-1.98 \\
(0.61)\end{array}$ & $\begin{array}{l}-15.14^{* * *} \\
(0.00)\end{array}$ & $\begin{array}{l}-3.89 \\
(\mathrm{BP}=1928)\end{array}$ & $\begin{array}{l}-8.30^{* * *} \\
(\mathrm{BP}=1934)\end{array}$ & $\mathrm{I}(1)$ \\
\hline $\begin{array}{l}\text { Patent } \\
\text { applications } \\
{[\ln X]}\end{array}$ & $\begin{array}{l}-2.81 \\
(0.20)\end{array}$ & $\begin{array}{l}-7.72^{* * *} \\
(0.00)\end{array}$ & $\begin{array}{l}-2.90 \\
(0.17)\end{array}$ & $\begin{array}{l}-17.28^{* * * *} \\
(0.00)\end{array}$ & $\begin{array}{l}-3.91 \\
(\mathrm{BP}=1885)\end{array}$ & $\begin{array}{l}-7.89^{* * *} \\
(\mathrm{BP}=1890)\end{array}$ & $\mathrm{I}(1)$ \\
\hline Labour Force & $\begin{array}{l}-3.78^{* * *} \\
(0.02)\end{array}$ & $\begin{array}{l}-7.79^{* * *} \\
(0.00)\end{array}$ & $\begin{array}{l}-3.64^{* *} \\
(0.03)\end{array}$ & $\begin{array}{l}-7.39^{* * *} \\
(0.00)\end{array}$ & $\begin{array}{l}-4.12 \\
(\mathrm{BP}=1918)\end{array}$ & $\begin{array}{l}-8.28^{* * *} \\
(\mathrm{BP}=1915)\end{array}$ & $\mathrm{I}(0) / \mathrm{I}(1)$ \\
\hline $\begin{array}{l}\text { Population } \\
{[\ln P]}\end{array}$ & $\begin{array}{l}-2.71 \\
(0.23)\end{array}$ & $\begin{array}{l}-4.55^{* * *} \\
(0.00)\end{array}$ & $\begin{array}{l}-2.71 \\
(0.23)\end{array}$ & $\begin{array}{l}-4.66^{* * *} \\
(0.00)\end{array}$ & $\begin{array}{l}-3.31 \\
(\mathrm{BP}=1873)\end{array}$ & $\begin{array}{l}-5.70^{* *} \\
(\mathrm{BP}=1866)\end{array}$ & $\mathrm{I}(1)$ \\
\hline $\begin{array}{l}\text { Patent appl./ } \\
\text { labour force } \\
{[\ln (X / L)]}\end{array}$ & $\begin{array}{l}-3.65^{* * *} \\
(0.03)\end{array}$ & $\begin{array}{l}-8.65^{* * *} \\
(0.00)\end{array}$ & $\begin{array}{l}-3.54^{* *} \\
(0.04)\end{array}$ & $\begin{array}{l}-8.65^{* * *} \\
(0.00)\end{array}$ & $\begin{array}{l}-4.90^{*} \\
(\mathrm{BP}=1988)\end{array}$ & $\begin{array}{l}-9.27^{* * *} \\
(\mathrm{BP}=1900)\end{array}$ & $\mathrm{I}(0)$ \\
\hline
\end{tabular}

Note: $\mathrm{p}$-values for the ADF and PP tests are indicated in parentheses. For the Zivot-Andrews tests in levels, the $1 \%, 5 \%$ and $10 \%$ critical values are $-5.57,-5.08$ and -4.82 , respectively. In firstdifferenced form, the values are $-5.43,-4.80$ and -4.58 , respectively. The endogenously determined break point (BP) for each series is indicated in parentheses. ${ }^{*},{ }^{*}$ and ${ }^{* * *}$ indicate $10 \%, 5 \%$ and $1 \%$ significance, respectively.

Next, a cointegration test is carried out following Equation (6) using Johansen (1988) method to examine the relationship between patent applications $(X)$ and labour force $(L)$. Vector error correction method (VECM) is employed to calculate the error correction term associated with the $\ln X$ variable. To analyse the three-act growth dynamics discussed in Section 1, the following sample periods were considered: 1840-1890, 1891-1940, 19411970 and 1971-2008, respectively. The first sample period indicates the pre-depression period, which is the period of growth following the Australian gold rush in the 1850s and commodity export-led growth. 
The following period 1890-1940 is the recession gap, where Australia struggled to achieve any positive growth. Consequently, 1940-1970 is the recovery or post-war boom era, where Australia matched with most other OECD countries. Finally, 1970-2008 is the period where, like all other OECD countries, Australian TFP growth slowed down. In the empirical estimates, the period of $1840-2008$ is included to account for the overall relation between the variables in the past two centuries.

Table 2: Cointegration Test between Patent Applications and Labour Force (Eq. (6))

\begin{tabular}{llllll}
\hline \hline Period & Hypothesis & Trace statistic & $\begin{array}{l}\text { Max-Eigenvalue } \\
\text { statistic }\end{array}$ & $\begin{array}{l}\text { Cointegrating } \\
\text { vector }\end{array}$ & ECT \\
\hline $1840-1890$ & $r=0$ & $19.30^{* * * *}$ & $15.92^{* * * *}$ & $1,-3.06^{* * *}$ & $-0.72^{* * *}$ \\
& $r \leq 1$ & 3.38 & 3.38 & {$[-25.96]$} & {$[-3.99]$} \\
$1891-1940$ & $r=0$ & $21.46^{* * *}$ & $17.91^{* * *}$ & $1,0.03$ & $-0.11^{* * *}$ \\
& $r \leq 1$ & 3.55 & 3.55 & {$[0.07]$} & {$[3.94]$} \\
$1941-1970$ & $r=0$ & $19.92^{* * *}$ & $15.36^{* * *}$ & $1,-0.79^{* * *}$ & $-0.48^{* * *}$ \\
& $r \leq 1$ & 4.56 & 4.56 & {$[-4.96]$} & {$[-2.40]$} \\
$1971-2008$ & $r=0$ & $22.72^{* * *}$ & $15.99^{* * *}$ & $1,1.58^{* * *}$ & $-0.13^{* * * *}$ \\
& $r \leq 1$ & 6.74 & 6.74 & {$[3.62]$} & {$[-2.89]$} \\
$1840-2008$ & $r=0$ & $19.85^{* * *}$ & $19.03^{* * *}$ & $1,-1.33^{* * *}$ & $-0.02^{* * *}$ \\
& $r \leq 1$ & 0.82 & 0.82 & {$[-17.80]$} & {$[-2.29]$} \\
\hline \hline
\end{tabular}

Note: The null hypothesis is that there are $\mathrm{r}$ cointegrated relationships between the variables. An intercept but no trend is included in the estimation. The optimal lag length is determined by AKC. Critical values are taken from Mackinnon et al. (1999). ECT is the error correction term associated with the $\Delta \ln \mathrm{X}$ equation. Figures in parentheses are t-statistics. ${ }^{*},{ }^{* * *}$ and ${ }^{* * *}$ indicate $10 \%, 5 \%$ and $1 \%$ levels of significance, respectively.

Cointegration results in Table 2 shows that the null of no cointegration is not rejected only for the periods 1891-1940 and 1971-2008, respectively. In all other occurrences, the null of $r=0$ is rejected in favour of $r \leq 1$. Although in the period 1891-1940, trace and maximum-Eigen value statistics are significant, the coefficient of labour force in the cointegrating vector is insignificant. The results support the prediction of Schumpeterian theory of higher research intensity-led growth for the sample periods 1840-1890 and 19401970, respectively. Together, both sample periods indicate positive productivity growth for the Australian economy. 
Table 3: Productivity Growth Estimates of Equation (8)

\begin{tabular}{|c|c|c|c|c|c|}
\hline \multicolumn{6}{|c|}{ Dependent Variable: $\triangle \ln T F P$ (Total factor productivity) } \\
\hline$X / Q$ & $\Delta \ln P$ & $D$ & $\triangle \ln T O$ & $\triangle \ln L E$ & $\ln U N C$ \\
\hline $0.12^{* *}$ & $-0.69^{* *}$ & $-0.13^{* * *}$ & & & \\
\hline$(0.02)$ & $(0.02)$ & $(0.01)$ & & & \\
\hline $0.12^{* *}$ & $-0.72^{*}$ & $-0.13^{* * *}$ & -0.02 & & \\
\hline$(0.03)$ & $(0.08)$ & $(0.01)$ & $(0.86)$ & & \\
\hline $0.12^{* * *}$ & $-1.22^{* *}$ & $-0.08^{* *}$ & 0.06 & $-3.50^{* * *}$ & $0.07^{* *}$ \\
\hline$(0.03)$ & $(0.02)$ & $(0.04)$ & $(0.47)$ & $(0.00)$ & $(0.02)$ \\
\hline \multicolumn{6}{|c|}{ Dependent Variable: $\Delta \ln L P$ (Labour productivity) } \\
\hline $0.05^{* *}$ & $-0.46^{* *}$ & $-0.12^{* * *}$ & & & \\
\hline$(0.05)$ & $(0.05)$ & $(0.00)$ & & & \\
\hline $0.05^{*}$ & $-0.61^{* *}$ & $-0.12^{* * *}$ & -0.12 & & \\
\hline$(0.08)$ & $(0.05)$ & $(0.00)$ & $(0.23)$ & & \\
\hline $0.05^{* *}$ & $-0.96^{* *}$ & $-0.08^{* * *}$ & -0.05 & $-3.05^{* * *}$ & 0.03 \\
\hline$(0.05)$ & $(0.02)$ & $(0.01)$ & $(0.26)$ & $(0.00)$ & $(0.38)$ \\
\hline
\end{tabular}

Note: p-values are indicated in parentheses. $\mathrm{D}$ is the dummy variable, which takes value one corresponding to the period 1890-1940, and zero otherwise. The Newey-West procedure was used to obtain heteroskedasticity consistent robust estimates. An intercept was included in the estimation but the estimates are not reported. All series are in five years non-overlapping. ${ }^{*},{ }^{* *}$ and ${ }^{* * * *}$ indicate $10 \%$, $5 \%$ and $1 \%$ levels of significance, respectively.

To see the effect of research intensity and population growth on the productivity growth of Australia, next a regression is run following Equations (8) and (9) respectively. Table 3 presents the results following Equation (8). Table 4 presents the results following Equation (9), where research intensity and population growth enter into the regression models with one period lag. To account for the recession in the period 1891-1940, a dummy variable (D) is introduced in the regression models, which takes the value of one between 1891 and 1940 and zero otherwise. If the dummy variable is found to be significant and negative, it would suggest that there was significant growth drag present in the period.

The growth estimation results presented in Table 3 and Table 4 show that research intensity in the economy positively influences productivity growth in all occurrences. The result is true for both total factor productivity growth and labour productivity growth estimations. Moreover, the results are robust to the use of different control variables. Population growth has negative effect on productivity growth, where the coefficient is 
negative and significant in all cases. Moreover, the dummy variable (D) is negative and significant in all occurrences, which indicates slower productivity growth in the period 18901940

Table 4: Productivity Growth Estimates of Equation (9)

\begin{tabular}{|c|c|c|c|c|c|}
\hline \multicolumn{6}{|c|}{ 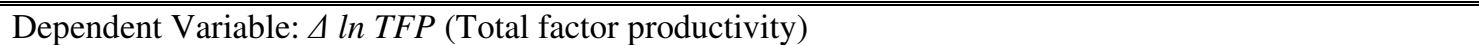 } \\
\hline$(X / Q)_{t-1}$ & $\Delta \ln P_{t-1}$ & $D$ & $\triangle \ln T O$ & $\Delta \ln L E$ & $\ln U N C$ \\
\hline $0.08^{* * * * *}$ & $-0.90^{* * * *}$ & $-0.08^{* * * *}$ & & & \\
\hline$(0.01)$ & $(0.00)$ & $(0.01)$ & & & \\
\hline $0.08^{* * * * *}$ & $-0.90^{* * * *}$ & $-0.08^{* * *}$ & 0.00 & & \\
\hline$(0.01)$ & $(0.00)$ & $(0.01)$ & $(0.96)$ & & \\
\hline $0.09^{*}$ & $-1.03^{* * *}$ & -0.04 & 0.08 & $-2.90^{* *}$ & 0.07 \\
\hline$(0.07)$ & $(0.00)$ & $(0.17)$ & $(0.18)$ & $(0.02)$ & $(0.15)$ \\
\hline \multicolumn{6}{|c|}{ Dependent Variable: $\Delta \ln L P$ (Labour productivity) } \\
\hline $0.05^{* *}$ & $-0.42^{*}$ & $-0.10^{* * * 3}$ & & & \\
\hline$(0.03)$ & $(0.09)$ & $(0.00)$ & & & \\
\hline $0.04^{* * *}$ & $-0.48^{*}$ & $-0.10^{* * * *}$ & -0.10 & & \\
\hline$(0.02)$ & $(0.07)$ & $(0.00)$ & $(0.31)$ & & \\
\hline $0.06^{* * *}$ & $-0.50^{*}$ & $-0.06^{* * *}$ & -0.02 & $-2.42^{* * *}$ & 0.02 \\
\hline$(0.04)$ & $(0.06)$ & $(0.01)$ & $(0.65)$ & $(0.00)$ & $(0.50)$ \\
\hline
\end{tabular}

Note: $p$-values are indicated in parentheses. $\mathrm{D}$ is the dummy variable, which takes the value of one corresponding to the period 1890-1940, and zero otherwise. The Newey-West procedure was used to obtain heteroskedasticity-consistent robust estimates. An intercept was included in the estimation but the estimates are not reported. All series are in five-year non-overlapping series. ${ }^{*},{ }^{* *}$ and ${ }^{* * *}$ indicate $10 \%, 5 \%$ and $1 \%$ levels of significance, respectively.

Trade openness was not significant in any of the cases, which suggests that it was not influential for productivity growth in Australia. This finding supports McLean (2004), who argues that higher commodity export was a characteristic of Australian growth in both centuries and was not the major cause of the depression around the 1890s. Other control variables, such as life expectancy and macroeconomic uncertainty do not show the right sign and are insignificant in many occurrences.

Jackson (1992) finds that life expectancy and leisure rapidly increased in Australia in the depression period of 1890-1926, but the rate then slowed in the period 1927-1972. This might be why LE is found to be negatively significant in the regression estimates. Life expectancy in Australia grew faster during a period of slower productivity growth, and at a 
slower rate during higher productivity growth. In this scenario, it is not surprising that the empirical results show an adverse relation between life expectancy and productivity growth. Nevertheless, the results are robust in terms of the effects of innovative activity and population growth in Tables 3 and 4, respectively.

\section{Conclusion}

Even though the importance of innovative activity has been widely accepted in the literature, such as in the context of the Industrial Revolution in Britain or productivity growth in OECD countries in the recent past, few studies have focused on its relevance in the context of Australian productivity growth during the depression years of 1891-1940. Further, in terms of the present political debate concerning the opening up of Australia's borders to the international world, it is important to examine empirically the role of population growth in the country's historical growth. Consequently, these missing gaps in the literature need immediate attention from researchers that might provide some severe policy implications for the future. This study examines the roles of endogenous technological progress and population growth in advancing the productivity growth of Australia since 1840. Moreover, considering the wide acceptance of the predictions of Schumpeterian growth theory in various empirical studies in recent times, the paper tests whether Australian productivity growth follows the predictions of the second-generation Schumpeterian growth model.

Crafts and Mills (2009) in their concluding remarks suggest that in modelling the transition to modern economic growth, economists should focus more on the improvements in capabilities and in incentive structures that increased the probability of technological advance. The results in this study show that technological progress has a significant positive effect on productivity growth in Australia since the 1840s. Slower productivity growth was responsible for sluggish economic growth in the first half of the twentieth century, where the 
dummy variable was negatively significant in all growth regression estimates. The results are in favour of Kaspura and Weldon (1980), who argue that Australia lagged behind the US in the twentieth century because of the slower transition of factor accumulation to total factor productivity growth. Further, the effect of population growth is negative on productivity growth in Australia at all times. When land is a factor of production, higher population growth acts as drag on productivity growth. At that point, productivity growth becomes a race between technological progress on the one hand and population growth on the other. Sustained technological progress can maintain the productivity growth of the economy by outpacing the population growth rate. This supports the findings of Madsen, et al. (2010a) and Ang, et al. (2010). The finding indeed has some serious policy implications for recent times.

Finally, the empirical estimates give strongly support the Schumpeterian growth hypothesis, which predicts that growth is driven by the levels of research intensity in the economy. This implies that R\&D has permanent growth effects in the long run and that the productivity growth rate remains constant and positive as long as the number of researchers is kept to a constant proportion of the number of product lines or the size of the population. The finding is consistent with earlier findings by Ha and Howitt (2007), Madsen (2008), Madsen, et al. (2010a) and Madsen, et al. (2010b). 


\section{Data Appendix and Sources}

TFP: Total Factor Productivity is measured following Equation (1):

$$
\begin{aligned}
Y_{t}= & A_{t} K_{t}^{\alpha\left(1-\beta_{t}\right)} T_{t}^{\beta_{t}} L_{t}^{(1-\alpha)\left(1-\beta_{t}\right)} \\
& \Rightarrow A_{t}=\frac{Y_{t}}{K_{t}^{\alpha\left(1-\beta_{t}\right)} T_{t}^{\beta_{t}} L_{t}^{(1-\alpha)\left(1-\beta_{t}\right)}}
\end{aligned}
$$

where $\beta_{\mathrm{t}}$ is the share of land in total income, measured as real GDP in agriculture divided by real aggregate GDP. $\beta_{t}$ is allowed to vary over time, since it is apparent that as an economy grows over time, the share of agriculture in total income will fall and land will become less and less important in the production process. Capital share is $\alpha\left(1-\beta_{\mathrm{t}}\right)$, where $\alpha$ takes the value of 0.3 . Correspondingly, labour share becomes $(1-\alpha)\left(1-\beta_{\mathrm{t}}\right)$. Capital and GDP are measured in purchasing power parity units. Capital stock is calculated from investment series using a perpetual inventory method with 8 per cent depreciation rate. Labour inputs are measured by annual hours worked multiplied by economy-wide employment. Thus it takes into account the fact that the labour force participation rate and annual hours worked have changed substantially over time.

GDP: Aggregate real GDP in the period 1840-1900 is taken from the dataset compiled by Angus Maddison, which is available online at www.ggdc.net/maddison. 1901-1959 is taken from Maddock and McLean (1987), Table 4, p.362, which is based on Butlin (1977) and ABS catalogue number 5204. Finally 1960-2008 is from the OECD statistical database www.oecd-ilibrary.org. The series were spliced together to get a continuous annual series from 1840-2008. For agricultural real GDP 1860-1937 is from Haig (2001); 1937-1969 is from Australian Historical Statistics by Vamplew (1987); 1960-2008 is from the OECD statistical database www.oecd-ilibrary.org. There is no continuous agricultural GDP data before 1860. Data points in the period 1840-1860 are extrapolated backwards on the basis of the annual geometric growth rate in the period 1860-1880. 
Patent applications: Data are based on 'patents applied to residents' only from the World Intellectual Property Organisation (WIPO) www.wipo.int/ipstats/en/statistics/patents. Missing years were extrapolated backwards.

Capital stock: Gross fixed capital formation at real prices in the period 1861-1959 is taken from Mitchell (2007), p.1016. 1960-2008 is from the OECD statistical database: www.oecd-ilibrary.org. Missing data before 1860 are extrapolated backwards on the basis of annual geometric growth rate in the period $1860-1880$.

Labour force: 1840-1901 is from Vamplew (1987), p. 149. The data points are in decadal form, hence missing years were interpolated. 1901-1963 is from Maddock and McLean (1987), Table 4, p.362. 1964-2008 is from the OECD statistical database www.oecd-ilibrary.org.

Annual hours worked per worker: $1890-1977$ is from Clark (1957). 1978-2008 is from the OECD statistical database: www.oecd-ilibrary.org.

Land: $1850-1960$ is from Australian Historical Statistics by Vamplew (1987), p.74. 1961-2008 is from the FAO statistical database: http://faostat.fao.org.

Trade openness: Trade openness is measured by the sum of total exports and imports divided by nominal GDP. Exports and imports for the period 1840-1900 are taken from Mitchell (2007), p.535; 1901-1981 from Maddock and McLean (1987), Table 3, p.359; 1981-2008 from World Development Indicators (WDI) online database: http://data.worldbank.org/data-catalog.

Macro uncertainty: The measure of macro uncertainty is calculated as five years' standard deviation of annual growth rate of Consumer Price Index (CPI) series. CPI in the period 1840-1860 is extrapolated backwards on the basis of the annual geometric growth rate of 1860-1880; 1861-1955 is from Mitchell (2007), p.939; 1956-2008 is from the OECD statistical database www.oecdilibrary.org. 
Life expectancy: $1840-1880$ is from by Vamplew (1987), p.60; 1881-1959 is from the Australian Bureau of Statistics (ABS) www.abs.gov.au; 1960-2008 is from World Development Indicators (WDI) online database: data.worldbank.org/data-catalog.

Population: 1840-1955 is from the dataset compiled by Angus Maddison, available online at www.ggdc.net/maddison/. 1956-2008 is from the OECD statistical database www.oecd-ilibrary.org. 


\section{References}

Aghion, P. and Howitt, P. (1992), 'A Model of Growth Through Creative Destruction', Econometrica, 60, 323-351.

Aghion, P. and Howitt, P. (1998), Endogenous Growth Theory, The MIT Press, Cambridge.

Ang, J., Banerjee, R. and Madsen, J.B. (2010), 'Innovation, Technological Change and the British Agricultural Revolution'CAMA Working Papers 2010-11, Australian National University, Centre for Applied Macroeconomic Analysis.

Boehm, E.A. (1971), Prosperity and depression in Australia, 1887-1897, Clarendon Press, Oxford.

Boehm, K. and Silberston, A. (1967), The British Patent System: Administration, Cambridge University Press, Cambridge.

Butlin, M.W. (1977), 'A Preliminary Annual Database: 1900/01-1973/74'Research Discussion Paper 7701, Reserve Bank of Australia, Sydney.

Butlin, N.G. (1962), Australian Domestic Product, Investment and Foreign Borrowing, 1861 1938/39, Cambridge University Press, Cambridge.

Cervellati, M. and Sunde, U. (2005), 'Human Capital Formation, Life Expectancy, and the Process of Development', American Economic Review, 95, 1653-1672.

Clark, C. (1957), The Conditions of Economic Progress London: Macmillan.

Crafts, N. and Mills, T.C. (2009), 'From Malthus to Solow: How did the Malthusian economy really evolve?', Journal of Macroeconomics, 31, 68-93.

Galor, O. and Weil, D.N. (2000), 'Population, Technology, and Growth: From Malthusian Stagnation to the Demographic Transition and beyond', American Economic Review, 90, 806-828.

Goodfriend, M. and McDermott, J. (1995), 'Early Development', American Economic Review, 85, 116-133.

Greasley, D. and Oxley, L. (1997), 'Segmenting the contours: Australian economic growth 1828-1913', Australian Economic History Review, 37, 39-53.

Greasley, D. and Oxley, L. (1998), 'A Tale of Two Dominions: Comparing the Macroeconomic Records of Australia and Canada Since 1870', The Economic History Review, 51, 294-318.

Greasley, D. and Oxley, L. (2007), 'Patenting, intellectual property rights and sectoral outputs in Industrial Revolution Britain, 1780-1851', Journal of Econometrics, 139, 340-354.

Griliches, Z. (1990), 'Patent statistics as economic indicators: A survey', Journal of Economic Literature, 27, 1661-1707.

Ha, J. and Howitt, P. (2007), 'Accounting for Trends in Productivity and R\&D: A Schumpeterian Critique of Semi-Endogenous Growth Theory', Journal of Money, Credit and Banking, 39, 733-774.

Haig, B. (2001), 'New Estimates of Australian GDP, 1861-1948/49', Australian Economic History Review, 41, 1-34.

Hansen, G.D. and Prescott, E.C. (2002), 'Malthus to Solow', American Economic Review, 92, 1205-1217.

Howitt, P. (1999), 'Steady Endogenous Growth with Population and R \& D Inputs Growing', Journal of Political Economy, 107, 715-730.

Jackson, R.V. (1977), Australian Economic Development in the Nineteenth Century, Australian National University Press, Canberra. 
Jackson, R.V. (1992), 'Trends in Australian Living Standards since 1890', Australian Economic History Review, 32, 24-46.

Johansen, S. (1988), 'Statistical analysis of cointegration vectors', Journal of Economic Dynamics and Control, 12, 231-254.

Jones, C.I. (1995a), 'R \& D-Based Models of Economic Growth', Journal of Political Economy, 103, 759-784.

Jones, C.I. (1995b), 'Time Series Tests of Endogenous Growth Models', Quarterly Journal of Economics, 110, 495-525.

Kaspura, A. and Weldon, G. (1980), 'Productivity Trends in the Australian Economy 1900-01 - 1978-79'Working Paper No. 9, Research Branch, Department of Productivity., Canberra.

Klenow, P.J. and Rodriguez-Clare, A. (1997), 'The Neo-classical Revival in Growth Economics: Has It Gone Too Far?', NBER Macroeconomics Annual, 12, 73-103.

Lucas, R.E. (2009), 'Trade and the Diffusion of the Industrial Revolution', American Economic Journal: Macroeconomics, 1, 1-25.

Mackinnon, J.G., Haug, A.A. and Michelis, L. (1999), 'Numerical Distribution Functions of Likelihood Ratio Tests for Cointegration', Journal of Applied Econometrics, 14, 563577.

Maddock, R. and McLean, I.W. (1987), The Australian economy in the long run, Cambridge University Press, New York.

Madsen, J., Ang, J. and Banerjee, R. (2010a), 'Four centuries of British economic growth: the roles of technology and population', Journal of Economic Growth, 15, 263-290.

Madsen, J.B. (2007), 'Are there diminishing returns to R\&D?', Economics Letters, 95, 161166.

Madsen, J.B. (2008), 'Semi-endogenous versus Schumpeterian growth models: testing the knowledge production function using international data', Journal of Economic Growth, 13, 1-26.

Madsen, J.B., Saxena, S. and Ang, J.B. (2010b), 'The Indian growth miracle and endogenous growth', Journal of Development Economics, 93, 37-48.

McLean, I.W. (2004), 'Australian Economic Growth in Historical Perspective*', Economic Record, 80, 330-345.

McLean, I.W. and Pincus, J.J. (1983), 'Did Australian Living Standards Stagnate between 1890 and 1940?', The Journal of Economic History, 43, 193-202.

Meredith, D. and Dyster, B. (1999), Australia in the Global Economy: Continuity and Change, Cambridge University Press, Cambridge.

Mitchell, B.R. (2007), International Historical Statistics: Africa, Asia \& Oceania 1750-2005 (5th ed.), Palgrave macmillan, New York.

Oxley, L. and Greasley, D. (1995), 'A Time-Series Perspective on Convergence: Australia, UK and USA since 1870', The Economic Record, 71, 259-270.

Oxley, L. and Greasley, D. (1998), 'Vector autoregression, cointegration and causality: testing for causes of the British industrial revolution', Applied Economics, 30, 13871397.

Peretto, P. and Smulders, S. (2002), 'Technological Distance, Growth and Scale Effects', The Economic Journal, 112, 603-624.

Romer, P.M. (1990), 'Endogenous Technological Change', Journal of Political Economy, 98, S71-102.

Sullivan, R.J. (1989), 'England's "Age of invention": The acceleration of patents and patentable invention during the industrial revolution', Explorations in Economic History, 26, 424-452. 
Sullivan, R.J. (1990), 'The Revolution of Ideas: Widespread Patenting and Invention During the English Industrial Revolution', The Journal of Economic History, 50, 349-362.

Vamplew, W. (1987), 'Australians, Historical Statistics, Vol. 10', Fairfax, Syme \& Weldon Associates, Broadway, N.S. W., Australia.

Zivot, E. and Andrews, D.W.K. (1992), 'Further Evidence on the Great Crash, the Oil-Price Shock, and the Unit-Root Hypothesis', Journal of Business \& Economic Statistics, 10 , 251-270. 